\title{
Rheological and Microbiological Study on Bio-Composites with Marine Chitosan Polymers from Black Sea Stone Crabs used in Medical Therapy of Tissue Regeneration
}

\begin{abstract}
RODICA SIRBU ${ }^{1}$, ALEF MUSTAFA ${ }^{1}$, ANETA TOMESCU ${ }^{2}$, GABRIELA STANCIU3*, EMIN CADAR ${ }^{1}$
${ }^{1}$ Ovidius University of Constanta, Faculty of Pharmacy, 124 Mamaia Blvd., 900527, Constanta, Romania 2Ovidius University of Constanta, Faculty of Medicine, 124 Mamaia Blvd., 900527, Constanta, Romania

${ }^{3}$ O vidius University of Constanta, Depart. of Chemistry and Chemical Engineering,124 Mamaia Blvd., 900527, Constanta, Romania

In the last years, health care professionals faced with an increasing number of patients suffering from wounds, burns and bedsores difficult to treat and heal. During the wound healing process, the dressing protects the injured area and contributes to the recovery of dermal and epidermal tissues. Because their biocompatibility, biodegradability and similarity to macromolecules recognized by the human body, some natural polymers such as polysaccharides (alginates, chitin, chitosan), proteoglycans and proteins (collagen, gelatin, fibrin) are extensively are used in wounds and burns management. The study presents a research of new semi-solid formulations of bio-composites based on chitosan extracted from the stone crab Pachygrapsus Mormoratus found on the Black Sea shores. The bio-composites were obtained from natural polymeric compounds, Chitosan (CT), hyaluronic acid (HA) and lanolin( $L)$, to which silver sulfadiazine (S), was added. Several semi-solid formulations have been performed for which the antimicrobial activity on gram-positive and gram-negative germ cultures and the rheological behavior was studied. The biocomposites that were obtained provide an optimal micro-environment for cell proliferation, migration and differentiation, due to their biocompatibility, biodegradability, peculiar structure and good antimicrobial activity.
\end{abstract}

Keywords: chitosan, hyaluronic acid, rheological behavior, antimicrobial activity

The skin is a dinamic protection tissue that acts as a hard barrier to prevent the invasion of different pathogens and dangerous substances having the role of a mechanical absorber [1]. However, the skin is permanently subject to various lesions and is injured by physical or chemical means. A damaged or injured area of the skin requires a series of complicated and well-designed events to reestablish its integrity and regain its normal function [2]. Wounds caused by burns, cuts, scratches, escapes, varicose ulcers, skin ulcerations, surgical wounds, sunburn, can be treated and healed by a complex process involving an integrated response by growth factors and many different types of cells to achieve a rapid restoration of the architecture and skin function [3]. Treating injuries in the oral or genital cavity is a current concern in modern medicine [4-8]. A scientific link has been made between skin and mucosal diseases with hereditary implications caused by the environmentor due to infections with various micro-organisms [7]. Currently used treatments following surgical interventions are preparations made from natural ingredients thathave antimicrobial activity and open wound healing properties. For a rapid and efficient restoration of tissues in the healing process, it is essential to provide an appropriate microclimate with optimum levels of moisture, oxygen and physical barriers to pathogenic microorganisms [9].

In 1962 G.D. Winter has proposed the use of wound dressing to provide the best conditions for wound regeneration [10]. In the treatment of wounds, modern bandages are used to aid in autolysis (non-invasive wound cleansing, keeping healthy tissue intact), stimulation of granulation tissue formation (new cell formation) and stimulation of epithelization (wound closure). There have been researches in the last decades of numerous materials that could accelerate wound healing [11]. Napkins, hydrogels, foams, hydrocolloidal compounds and transparent films for use in wound dressings in passive healing treatments have been recommended [12-13]. In the evolution of the wounds and in the treatment of the bedsores, another important risk factor generated by the bacteriological cultures, which is evidenced by the presence of more germs, is to be considered [14]. In this regard, the use of topical pharmaceutical formulations possessing obvious antibacterial activity is indicated. Due to their remarkable properties (biocompatibility, biodegradability), natural polymers are widely used in the field of regenerative medicine, for the treatment of wounds, burns and bedsores [15-16]. Currently, polysaccharide structures that are widely used to treat wounds, burns and bedsores can be neutral polysaccharides (glucans, dextrans, cellulose), acid polysaccharides (alginic acid, hyaluronic acid), basic polysaccharides (chitin, chitosan) or sulfate polysaccharides (heparin, dermatan sulfate, keratan sulfate) [17]. Recently, tissue replacement has become an option for skin tissue regeneration, especially for skin defects caused by burns, traumas or chronic wounds thatcan notbe cured. The use of biologically active natural and synthetic materials has evolved, having applications in wound healing and regeneration of skin tissues. In recent years, the continuous identification of new and useful natural biomaterials has led to the exploration of the marine ecosystem in search of new biologically active compounds [18]. As a result, in a short period of time, the marine ecosystem has been identified as an ideal source of biomaterials because it contains unlimited diversity [15-18]. The bio-composites presented in this paper are based on chitosan, a polysaccharide obtained from marine resources from the Black Sea, 
namely from Pachygrapsus Mormoratus crab. To achieve bio-composite topical formulations we combined this chitosan, obtained by extraction from Black Sea crab shell, with hydrated lanolin as natural emulsifier and hyaluronic acid (HA), another naturally nesulfated bio-polymer. To widen the antimicrobial activity of the bio-composites made from natural substances, we also introduced silver sulfadiazine. Several semi-solid formulations of chitosanbased bio-composites from Pachygrapsus Mormoratus were performed, for which rheological behaviors were studied, in order to assess the stability of the forms and also the antimicrobial activity on gram-positive and gramnegative germ cultures was tested.

\section{Experimental part}

Materials, extraction procedure of chitosan from Black Sea crabs

Chitosan was first obtained from Pachygrapsus mormoratus stone crabs from the Black Sea. The stone crabs were harvested from the Black Sea coast, from the coastal area of Navodari-Vadu shores, Constanta County, between June and July 2017. Chitin was extracted from the dried shells, chopped to a size between 0.5-5 $\mathrm{mm}$. The bio-technological process of obtaining chitosan from Pachygrapsus mormoratus crab shells was carried out in four stages: demineralization - which removes calcium carbonate and other minerals, deproteinization - a stage that dissolves proteins and carbohydrates, discoloration the process that extracts carotenoids and other dyes and deacetylation - which represents the process of transformation of chitin into chitosan.

\section{Chemicals}

All used reagents were of analytical reagent grade and were purchased from Sigma-Aldrich, Germany. Lanolin was purchased from Elemental, Romania, hyaluronic acid and silver sulfadiazine were purchased from SigmaAldrich, Germany. The tested microoganisms: Staphylococcus aureus (ATCC 65389P), Escherichia coli (ATCC 10536) and Candida albicans (ATCC 90028) were obtained from the Veterinary Health Directorate and Food Safety Division Constanta, Romania.

\section{Materials for Bio-composites with marine chitosan}

Bio-composites based on chitosan from the Black Sea as semisolid pharmaceutical forms were were prepared as four ointment-type pharmaceutical formulations containing: two differenttypes and proportions of chitosan (CT) extracted from Pachygrapsus Mormoratus originating from the Black Sea, associated with hyaluronic acid (AH), hydrated lanolin (L) as an $\mathrm{H} / \mathrm{L}$ emulsifier and silver sulfadiazine (S) in the ointment base. The four compositions are shown in table 1.

For sample C1 (L/CT code), in hydrated lanolin, which is one of the few materials capable of both solvent and surfactant properties, chitosan (which is a natural polysaccharide obtained from marine resources by the process presented in the paper) was introduced. Hydrated lanolin ( $25 \%$ water and $75 \%$ anhydrous lanolin) has a semisolid consistency, being a viscous, yellowish mass, with a characteristic smell and a melting point of $36-42^{\circ} \mathrm{C}$. Chitosan is in powder form and added in the proportion specified in Table 1. A semisolid preparation is obtained. Sample C2 (L/CT/AH code): over the hydrated lanolin (L) two polymers are added in equal proportions: chitosan powder (CT) with the polysaccharide structure and hyaluronic acid (HA) as an oily solution, a natural unsulphonated bio-polymer with known contributions to the functions biological processes such as cell adhesion, migration, differentiation and proliferation in tissue development [19-20]. The percentages of the three constituents are also shown in Table 1. An emollient semisolid preparation is obtained. Sample C3 (L/CT/S code) consists of hydrated lanolin (L) to which the chitosan powder (CT) and silver sulfadiazine (S) were added in the proportions indicated in table 1. A semi-solid biocomposite is obtained. Sample C4 (L/CT/AH/S code) consists of four components in the proportions indicated in table 1 . To the hydrated lanolin (L) the chitosan (CT) powder and the hyaluronic acid (HA) solution were added in equal proportions and in the end the silver sulfadiazine (S) powder. A biocomposite with very good consistency is obtained. The homogenization of the sample preparations was carried out by means of an electric homogenizer with a speed of 150 rpm for 5-10 min. All the samples have kept their consistency over time.

\section{Investigation methods}

Physico-chemical analyses for marine chitosan extracted from Pachygrapsus mormoratus

Characterization of chitosan was achieved by determining the qualitative attributes of physicochemical properties, such as: degree of deacetylation, and molecular weight.

\section{Degree of Deacetylation $D D$}

To determine the degree of deacetylation of a chitosan sample, a modified [21] method is used which consists in titrating the acid solution of chitosan with a standardized aqueous $\mathrm{NaOH}$ solution of known molar concentration close to $0.1 \mathrm{M}$. The $\mathrm{pH}$ values of the aqueous system are recorded according to the volume (in $\mathrm{mL}$ ) of standardized $\mathrm{NaOH}$ solution. At the end of the titration, the volume of standardized aqueous $\mathrm{NaOH}$ used only for the titration of the $-\mathrm{NH}_{3}{ }^{+}$groups is determined. The formula for calculating the degree of deacetylation of chitosan is given by equation (1):

$$
D D[\%]=2.03 \frac{V_{2}-V_{1}}{m+0.0042\left(V_{2}-V_{1}\right)}
$$

where: $m$-weight of sample, $V_{1}, V_{2}$-volumes of sodium hydroxide solu-tion corresponding to the deflection points, 2.03 -coefficient resulting from the molecular weight of chitin monomer unit, 0.0042 -coefficient resulting from the difference between molecular weights of chitin and chitosan monomer units [21].

Table 1

COMPOSITION OF REALIZED BIOCOMPOSITES

\begin{tabular}{|c|c|c|c|c|c|}
\hline Sample & $\begin{array}{l}\text { Code of } \\
\text { sample }\end{array}$ & $\begin{array}{l}\text { Lanolin } \\
L \\
\%\end{array}$ & $\begin{array}{l}\text { Chitosan } \\
C T \\
\%\end{array}$ & $\begin{array}{l}\text { Hyaluronic } \\
\text { acid } A H \\
\%\end{array}$ & $\begin{array}{l}\text { Silver } \\
\text { sulfadianine S } \\
\%\end{array}$ \\
\hline Sample Cl & $\mathrm{L} / \mathrm{CT}$ & 97.5 & 2.5 & - & - \\
\hline Sample C2 & $\mathrm{L} / \mathrm{CT} / \mathrm{HA}$ & 95.0 & 2.5 & 2.5 & - \\
\hline Sample C3 & $\mathrm{L} / \mathrm{CT} / \mathrm{S}$ & 96.5 & 2.5 & - & 1 \\
\hline Sample C4 & $\mathrm{L} / \mathrm{CT} / \mathrm{HA} / \mathrm{S}$ & 94.0 & 2.5 & 2.5 & 1 \\
\hline
\end{tabular}




\begin{tabular}{|c|c|c|c|c|}
\hline $\begin{array}{l}\text { Viscosity } n(c P) \\
\text { depending on shear } \\
\text { speed D }\left(\mathrm{sec}^{-1}\right)\end{array}$ & $\begin{array}{c}\text { Shear speed } D\left(\mathrm{sec}^{-J}\right) \\
\text { depending on shear } \\
\text { stress } \tau(P a)\end{array}$ & $\begin{array}{c}\text { Shear speed } D\left(\mathrm{sec}^{-1}\right) \text { in } \\
\text { correlation with the } \\
\text { selected rotation speed } \\
\omega(\text { rpm })\end{array}$ & $\begin{array}{c}\text { Shear stress } \tau(\mathrm{Pa}) \\
\text { depending on viscosity } \\
\eta(P) \text { and shear speed } D \\
\left(\mathrm{sec}^{-1}\right)\end{array}$ & $\begin{array}{c}\text { Table } 2 \\
\text { EQUATIONS USED IN } \\
\text { REOLOGICAL MEASUREMENTS } \\
\text { OF STUDIED }\end{array}$ \\
\hline$\eta=f(D)$ & $D=f(\tau)(4)$ & $\mathrm{D}=\omega * \mathrm{R}$ & $\tau=\eta * \mathrm{D}$ & $\mathrm{BIOCOI}$ \\
\hline
\end{tabular}

The equipment used was an SP10B pH electrode connected to a Consort C861 Multi-parameter analyzer pH meter which was mounted in the chitosan solution and recorded the $\mathrm{pH}$ of the solution after each $0.2 \mathrm{~mL}$ volume of $\mathrm{NaOH}$ solution added.

\section{Molecular weight (Mw) of chitosan}

The molecular weight ( $\mathrm{Mw}$ ) determination method is based on intrinsic viscosity measurements of chitosan solutions extracted from Pachygrapsus mormoratus crabs [22]. The intrinsic viscosity of the chitosan solution was measured in a buffer solution of acetic acid $0.2 \mathrm{M} / \mathrm{s}$ sodium acetate $0.1 \mathrm{M}$. The intrinsic or characteristic viscosities were determined by three successive measurements and taking into account the reduced and kinematic viscosities at infinite dilutions. We used the Mark-Houwink equation to determine the molecular weight [22]:

$$
[\eta]=k M^{a}
$$

where: $M$ is the average molecular weight, $[\eta]$ is the intrinsic viscosity, $k$ and $a$ are constants $\left(1.424 \times 10^{-5}(\mathrm{dL})\right.$ g) and 0.96 respectively).

The equipment used was a Ubbelohde-type capillary viscometer (produced bySCHOTT, Mainz Instruments) with a capillary constant of $0.009056 \mathrm{~mm}^{2} / \mathrm{s}^{2}$. The flow times were automatically measured with the Viscoclock measuring module, with a precision of $0.01 \mathrm{~s}$ [22].

\section{Rheological measurements for biocomposites}

For each sample, studies were conducted to highlight the rheological behavior of the biocomposites. The method of the cylindrical system with a known geometry was used and, knowing the rotation speed, the viscosity of the obtained preparations could be determined. The viscosity value corresponding to a given shear rate known as apparent viscosity (according to equation (3) of table 2) allows the viscosity curves to be obtained.

Knowing shear stress values $\tau$ and shear velocity $D$, we obtained the rheogramms for studied biocomposite preparations (according to relationship (4) of table 2). The calculation of shear speed $D\left(\mathrm{~s}^{-1}\right)$ is done using equation (5) in table 2, based on the values of the rotation speed $\omega$ (rpm). $R$ is a specific constant for each rotation axis that was used to calculate the shear rate $D$ in correlation with the selected rotation speed $\omega(\mathrm{rpm})$. Calculation of the shear stress $\tau$ is done with equation (6) of table 2 .

The work equipment with which the measurements were performed was a Reovasco-Star R rotational viscometer. The axes selected for these sample studies were R6 and R7, depending on the range of viscosity to be determined. The time intervals between the determinations and the duration of each measurement were $10 \mathrm{~s}$. The measurements were made by increasing/decreasing the rotational speed in the range of 4-200 rpm.

\section{Determination of Antimicrobial Activity of biocomposites Microorganisms and Culture Growth}

The microorganisms used for antimicrobial activity evaluation are the Gram-positive bacteria Staphylococcus aureus (ATCC 6538P), the gram-negative bacteria Escherichia coli (ATCC 10536) and a fungus species
Candida albicans ATCC 90028. For each of the strains we prepared a standard reference solution, an Inocculum, of a known concentration $\left(3 \times 10^{-8} / \mathrm{mL}\right)$. We used Petri dishes in which we added $1 \mathrm{~mL}$ of reference solution (Inocculum) and $80 \mathrm{~mL}$ of nonspecific nutrient agar, sterilized and homogenized. The plates thus prepared were allowed to cool, at room temperature until solidification of the agar. In parallel, we also prepared 3 positive control plates to compare the results obtained. After solidifying the agar from the Petri plates we made the wells, aseptically, using a sterilized matrix of known diameter.

\section{Antimicrobial Activity Assay}

The method of analysis used is the difuzometric method of Bauer A.W. (with some modifications) [23] with wells cut in the nonspecific nutrient agar medium. The biocomposite samples presented in table 1 were tested for their animicrobial activity. The work technique involves preparing the nonspecific nutrient agar plates filled with a known bacterial concentration and then measuring the inhibition halos formed by the chitosan solutions around the wells. These inhibition halos result from the activity of chitosan solutions on culture media by preventing the development of pathogens and their proliferation in the agar medium.

\section{Results and discussions}

Chitosan (with the polysaccharide structure [24-25]) is a cationic polymer composed of (1-4) -D-glucosamine and $\mathrm{N}$-acetyl-D-glucosamine and was obtained by partial or complete alkaline deacetylation of chitin. The scheme after which the chitosan from the Black Sea stone crabs was isolated is presented in figure 1 .

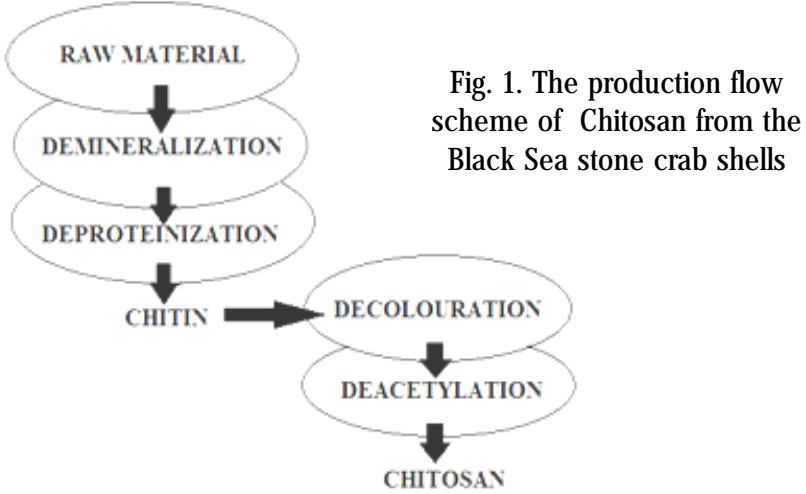

The technical conditions and results of each step are presented in table 3.

The deacetylation step involves the hydrolysis of chitin acetamide groups. Due to the resistance of these groups imposed by the trans-linkages between the substituents in the polysaccharide ring, the process requires a strong alkaline treatment [26]. The process of deacetylation of chitin to obtain the polymeric chitosan structures is schematically represented in Fig. 2[25].

Not all types of chitosan can be used for the same application and for this reason a correct and complete physical and chemical characterization of the extracted samples is required. For the obtained chitosan we analyzed the obtained degree of deacetylation (DD) and molecular weight (Mw). 
Table 3

STAGES OF THE CHITOSAN EXTRACTION PROCESS

\begin{tabular}{|c|c|c|c|c|}
\hline Step & Reagents & $\begin{array}{l}\text { Tempe- } \\
\text { rature }\end{array}$ & $\begin{array}{l}\text { Work } \\
\text { time }\end{array}$ & Result \\
\hline I-Demineralization & $\begin{array}{l}\mathrm{HCl} 1 \mathrm{~N}(1: 15 \\
\mathrm{w} / \mathrm{v})\end{array}$ & $30^{\circ} \mathrm{C}$ & $6 \mathrm{~h}$ & $\begin{array}{l}\text { The suspension was centrifuged for } 10 \mathrm{~min} \text {. at } 5300 \mathrm{rpm} \text {. } \\
\text { The collected powder has a high content of chitin extracted } \\
\text { from the crab shells. }\end{array}$ \\
\hline II-Deproteinization & $\begin{array}{l}\mathrm{NaOH} 3,5 \% \\
(1: 10 \mathrm{w} / \mathrm{v})\end{array}$ & $65^{\circ} \mathrm{C}$ & $2 \mathrm{~h}$ & $\begin{array}{l}\text { A suspension was obtained. It was centrifuged for } 15 \mathrm{~min} \text {. } \\
\text { at } 5300 \mathrm{rpm} \text {. The powder collected after washing was dried } \\
\text { at the oven at } 90^{\circ} \mathrm{C} \text { for } 48 \text { hours. }\end{array}$ \\
\hline III-Decolouration & $\begin{array}{l}\mathrm{NaOCl} \\
0,315 \%\end{array}$ & $20^{\circ} \mathrm{C}$ & $1 \mathrm{~h}$ & $\begin{array}{l}\text { The suspension was decanted, and the chitin powder was } \\
\text { collected and dried at the oven. }\end{array}$ \\
\hline IV-Deacetylation & $\begin{array}{l}\mathrm{NaOH} 50 \% \\
(1: 10 \mathrm{w} / \mathrm{v})\end{array}$ & $100^{\circ} \mathrm{C}$ & $5 \mathrm{~h}$ & $\begin{array}{l}\text { The process of transforming chitin into chitosan. After } \\
\text { boiling for } 5 \text { hours, the suspension was cooled for } 30 \\
\text { minutes at } 25^{\circ} \mathrm{C} \text { and after succesive washes with } 50 \% \\
\mathrm{NaOH} \text {, it was filtered. It was brought to } \mathrm{pH}=6 \text {. The } \\
\text { collected chitosan was dried at the oven. }\end{array}$ \\
\hline
\end{tabular}

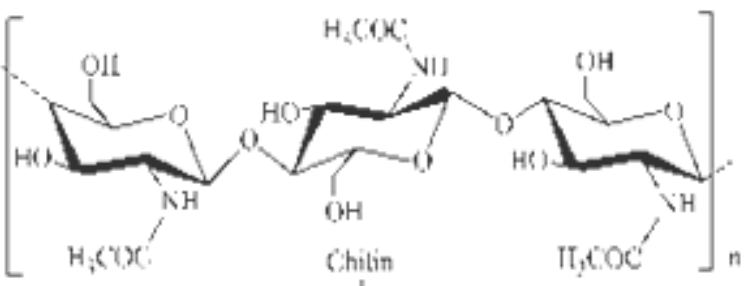

Table 4

VALUES OF VASCOSITY OBTAINED FOR THE EXTRACTED CHITOSAN (CT) SAMPLES

\begin{tabular}{|c|c|c|}
\hline $\begin{array}{c}\text { Concentration } \\
(c, g / d L)\end{array}$ & $\begin{array}{c}\text { Kinematic viscosity } \\
(v, c S t)\end{array}$ & $\begin{array}{c}\text { Low viscosity } \\
\left(\eta_{r e d}, d L / g\right)\end{array}$ \\
\hline 0,04680 & 1.1631 & 8.1977 \\
\hline 0.07488 & 1.392 & 8.7602 \\
\hline 0.11232 & 1.7328 & 9.4497 \\
\hline 0.14976 & 2.1093 & 10.0780 \\
\hline 0.18720 & 2.5321 & 10.7492 \\
\hline
\end{tabular}

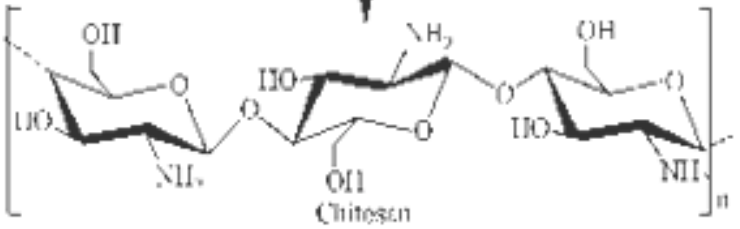

Fig. 2. Obtaining polymeric chitosan structures by chitin deacetylation

Degree of Deacetylation (DD)

The results obtained by applying the method described in the paper are shown in figure 3 , in which the titration curve (black color) and the corresponding derived curve (blue color) are presented for the titration of $0.2011 \mathrm{~g}$ of chitosan (CT) with a $0.0904 \mathrm{M}$ aqueous $\mathrm{NaOH}$ solution. From the volumes corresponding to the equivalence points the value $\Delta \mathrm{V}=9.2 \mathrm{~mL}$ was obtained. By applying equation (1) we obtained a degree of deacetylation of $\mathrm{DD} \%=71.5 \%$.

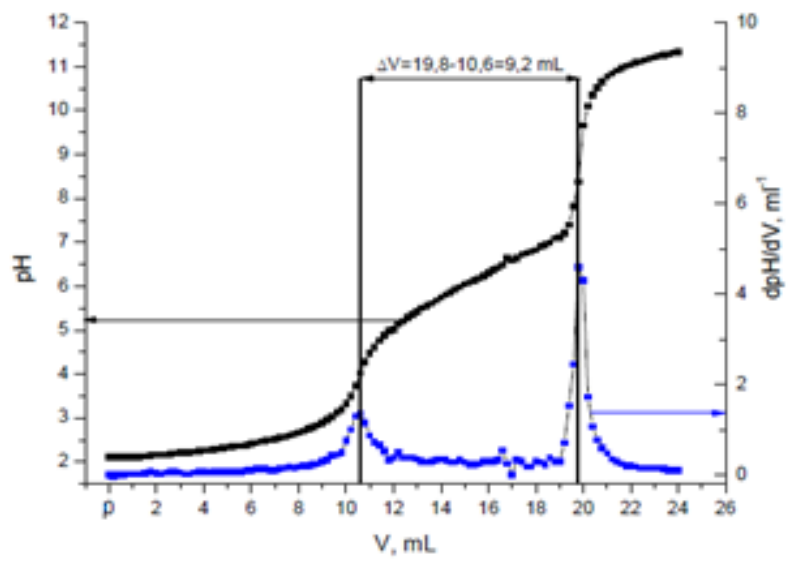

Fig. 3. The titration curve (black color) and the corresponding derived curve (blue color) for the titration of chitosan (CT) solution with a $0.0904 \mathrm{M}$ aqueous $\mathrm{NaOH}$ solution

\section{Molecular weight of Chitosan}

By applying the method we describe from rheology measurements we obtained the kinematic viscosity $(v)$ and the low viscosity $\left(\eta_{\text {red }}\right)$ values for extracted chitosan. These values are presented in table 4. concentration of the chitosan (CT) solution is shown in figure 4. The equation of the straight was obtained with a correlation coefficient R2 $=0.99960$ (fig.4). For the extracted chitosan (CT) sample, by applying equation (2), and by linear interpolation, we obtained a molecular weight value of $\mathrm{Mw}=8.98 \times 105 \mathrm{~g} / \mathrm{mol}$.

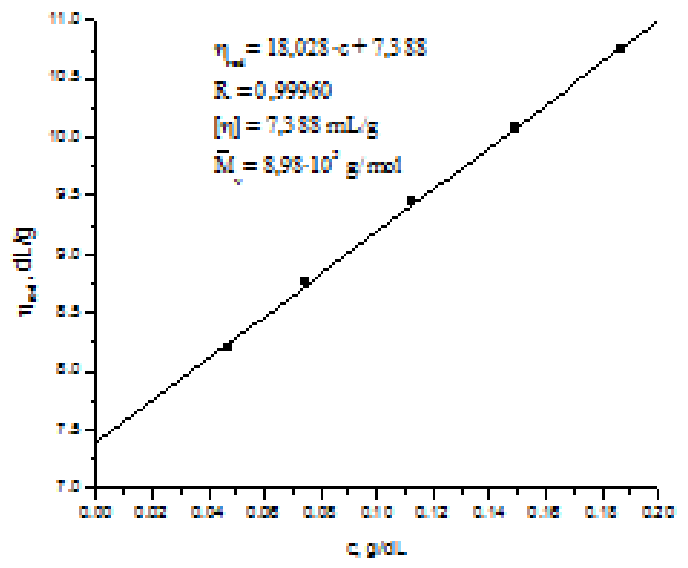

Fig. 4. The linear dependence of low viscosity on the concentration of the chitosan solution

\section{Chitosan-based Biocomposites}

The chitosan-based biocomposites we obtained according to table 1 were maintained at $4^{\circ} \mathrm{C}$. All samples presented homogeneous appearance and kept their consistency for 7 days, while they were tested. Biocomposite samples containing hyaluronic acid (C2 and C4) have been found to have a finer appearance and a lighter gray color than those with lanolin and chitosan (C1) which are more granular and have a darker yellowish-gray color.

\section{Rheological behavior of biocomposites}

In order to characterize the rheological behavior of all the biocomposites encoded in table 1 , the ranges of the values of the rheological parameters which were obtained by experimental results and calculation using the set of equations (3) - (6). are presented in table 5. 
Table 5

VALUE INTERVALS FOR REOLOGICAL PARAMETERS OBTAINED ON THE CHITOSAN-BASED BIOCOMPOSITES EXTRACTED FROM THE BLACK SEA

\begin{tabular}{|l|c|c|c|}
\hline \multicolumn{1}{|c|}{ Sample } & $\begin{array}{c}\text { Viscosity } \eta(\mathrm{cP}) \\
\text { The interval }\end{array}$ & $\begin{array}{c}\text { Shear speed } D\left(\text { sec }^{-1}\right) \\
\text { The interval }\end{array}$ & $\begin{array}{c}\text { Shear stress }(\tau) \text { Pa } \\
\text { The interval }\end{array}$ \\
\hline C1 code $L / C T$ & $24570-160800$ & $1.68-56$ & $41.3-9004.8$ \\
\hline$C 2$ code $L / C T / H A$ & $7820-132800$ & $1.40-56$ & $10.95-7436.8$ \\
\hline$C 3$ code $L / C T / S$ & $2500-39500$ & $1.36-68$ & $3.4-2686$ \\
\hline$C 4$ code $/ C T / H A / S$ & $1190-39200$ & $1.12-56$ & $1.33-2195.2$ \\
\hline
\end{tabular}

The rheological study of the biocomposite $C 1$ sample with the L/CT code is shown in figure 5 and was done by obtaining the rheogramm (fig.5a), by drawing the viscosity curve (fig. 5b) and by linearizing the viscosity curve (fig. $5 c)$.

In the graphs below, the obtained rheogramms show a pseudoplastic character of the prepared pharmaceutical forms. Viscosity decreases with increasing rotation speed.

After the linearization of the flow curves over a certain shear rate value, the prepared formulations retain the same structure. The rheological study of the biocomposite C 2 sample with the L/CT/HA code is shown in figur e6 and was done by obtaining the rheogramm (fig. 6a), by drawing the viscosity curve (shown in fig. 6b) and by linearizing the viscosity curve (shown in fig. 6c).

The rheological study of the biocomposite $C 3$ sample with the L/CT/S code is shown in figure7 and was done by obtaining the rheogramm (fig. 7a), by drawing the viscosity curve (shown in fig. 7b) and by linearizing the viscosity curve (shown in fig. 7c). For samples prepared with the addition of chitosan powder ( $\mathrm{C} 1$ and $\mathrm{C} 3$ ) an increase in viscosity at the same shear rate and also a change in color from light yellow to gray was observed.
The rheological study of the biocomposite $\mathrm{C} 4$ sample with the L/CT/HA/S code is shown in figure 8 and was done by obtaining the rheogramm (fig. 8a), by drawing the viscosity curve (shown in fig. 8b) and by linearizing the viscosity curve (shown in fig. 8c). In contrast, samples containing the association of chitosan and hyaluronic acid (C2 and C4) showed a decrease in viscosity values at the same shear rate.

The viscosity curves obtained for each biocomposite sample show a linearization of these curves at an increase in shear rate of over $20 \mathrm{~s}^{-1}$, which means that they exhibit an ideal plastic behavior at high shear rates over $20 \mathrm{~s}^{-1}$.

This aspect leads to the preservation of the structure of the analyzed pharmaceutical form. The results obtained from the study of the rheograms lead to the observation of a non-Newtonian, pseudoplastic and thixotropic character of the analyzed samples, exhibiting hysteresis with different aria due to different composites.

The rheological study on the samples prepared with and without addition of hyaluronic acid revealed a linearization of flow curves at low shear stress at the same shear rate.

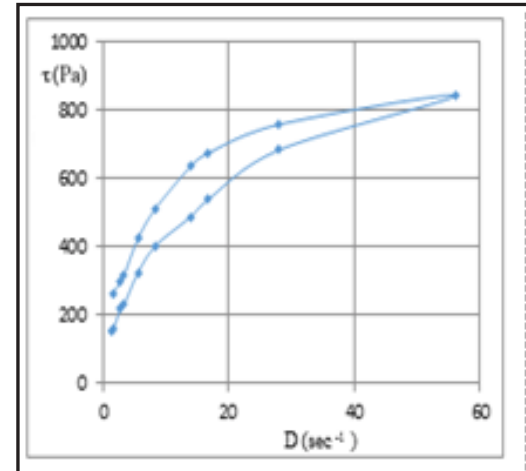

a) Rheogram for sample $A$ code $L / C T$

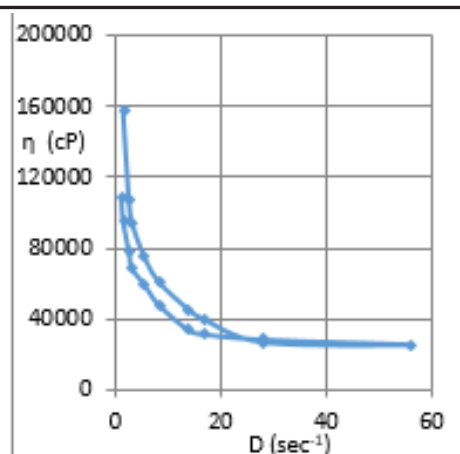

b) The viscosity curve for sample $A$ code $\mathrm{L} / \mathrm{CT}$

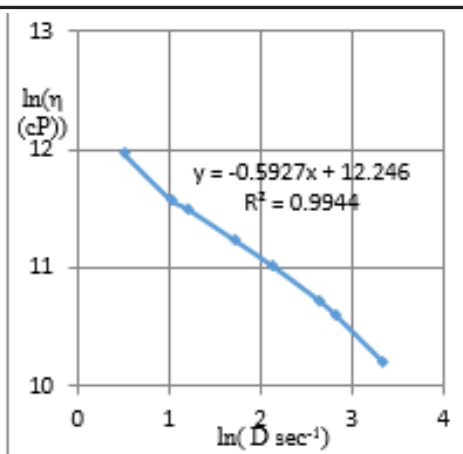

c) Linearization of the upward viscosity curve for sample A code L/CT

Fig.5. Results of rheological study for biocomposite A code L/CT

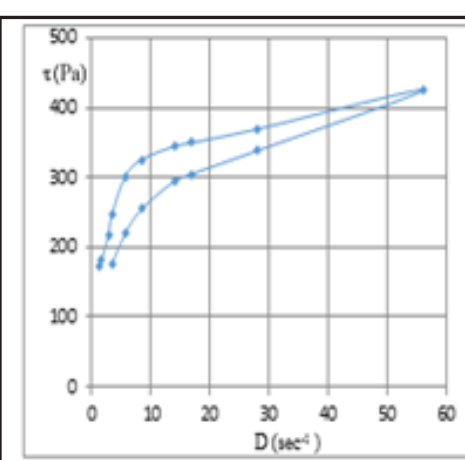

a) Rheogram for sample $B$ code $\mathrm{L} / \mathrm{CT} / \mathrm{HA}$

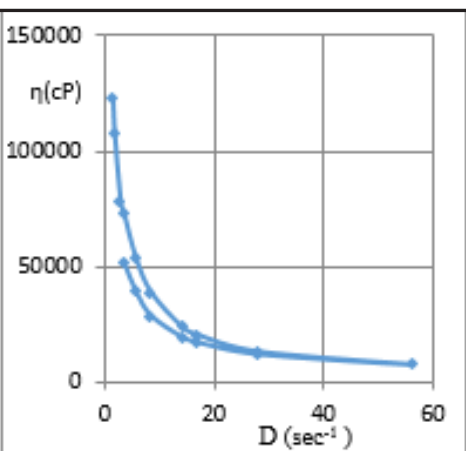

b) The viscosity curve for sample $B$ code L/CT/HA

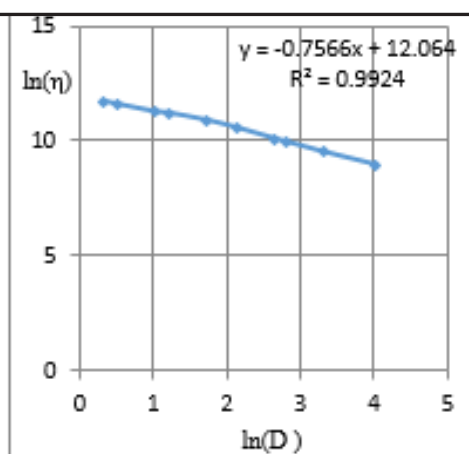

c) Linearization of the upward viscosity curve for sample $B$ code $\mathrm{L} / \mathrm{CT} / \mathrm{HA}$

Fig.6. Results of rheological study for biocomposite $B$ code L/CT/HA 


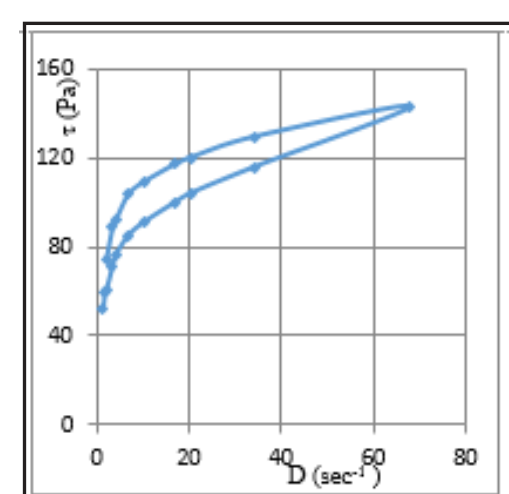

a) Rheogram for sample $\mathrm{C}$ code $\mathrm{L} / \mathrm{CT} / \mathrm{S}$

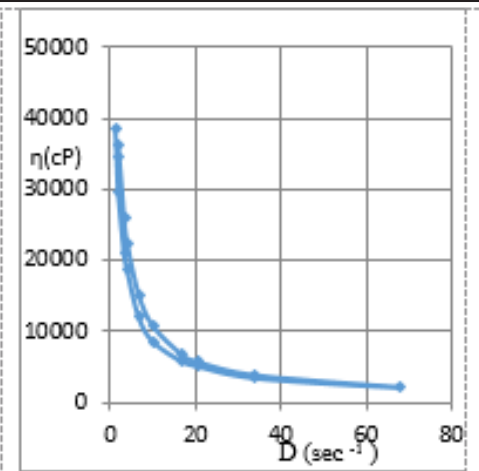

b) The viscosity curve for sample $\mathrm{C}$ code $\mathrm{L} / \mathrm{CT} / \mathrm{S}$

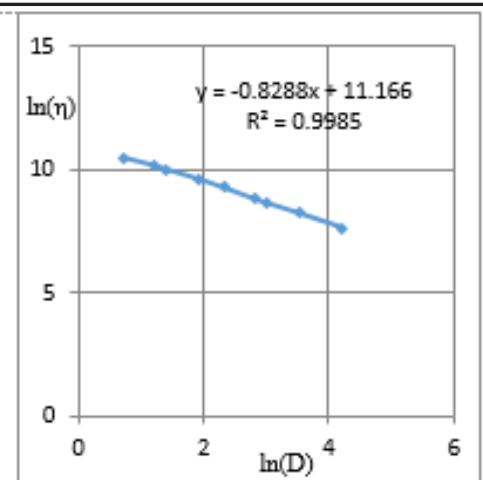

c) Linearization of the upward viscosity curve for sample $\mathrm{C}$ code $\mathrm{L} / \mathrm{CT} / \mathrm{S}$

Fig.7. Results of rheological study for biocomposite C cod L/CT/S

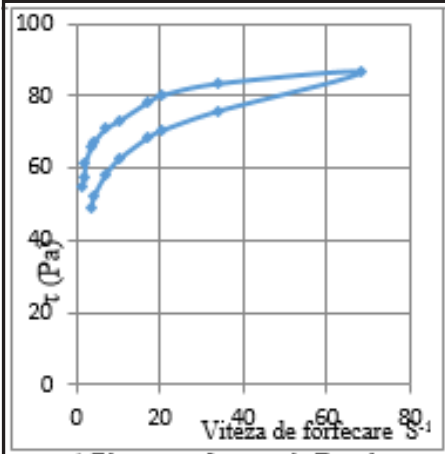

a) Rheogram for sample $\mathrm{D}$ code $\mathrm{L} / \mathrm{CT} / \mathrm{HA} / \mathrm{S}$

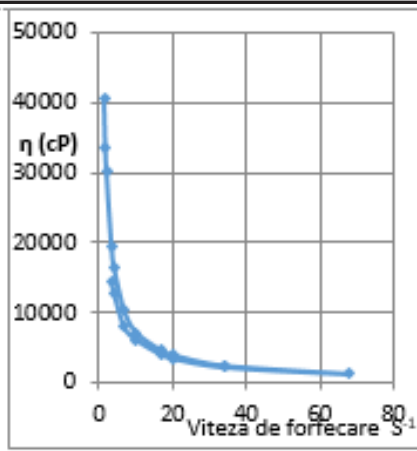

b) The viscosity curve for sample $\mathrm{D}$ code L/CT/HA/S

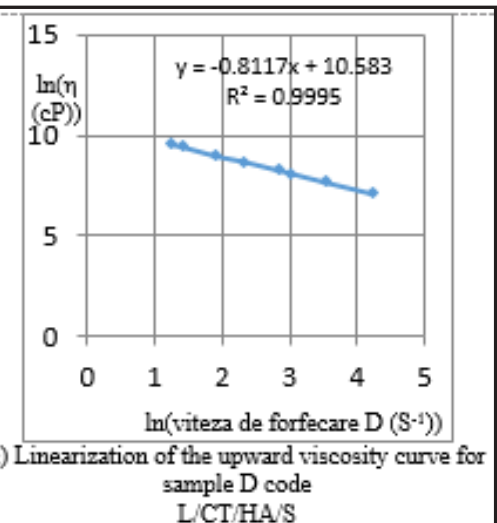
L/CT/HA/S

Fig. 8. Results of rheological study for biocomposite $D$ code L/CT/HA/S

\section{Antimicrobial activity}

A very important property of chitosan and of major interest in the pharmaceutical and medical field is the antimicrobial activity it exerts on various groups of microorganisms such as bacteria, molds and fungi.

In most of these studies, the action of chitosan is described as bactericidal (it kills live bacteria or some of them) or bacteriostatic (inhibits bacterial growth, but does not specify if bacteria are killed) often without a clear distinction between these actions. Recent research has shown a tendency to characterize chitosan as a bacteriostatic substance rather than bactericidal [26]. However, the mechanism of action is not very well understood, and many other factors can contribute to the antimicrobial property of chitosan [27]. Silver sulfadiazine has a broad antimicrobial activity. It is bactericidal for many gram-negative bacteria. Silver sulfadiazine is not an inhibitor of carbonic anhydrase and may be useful in situations where such agents are contraindicated. Antimicrobial activity was tested under the conditions described in the paper. The halo formed around the wells represents the inhibition of growth and stopping the spread of the pathogen and the rays differ depending on the composition of the analyzed samples (fig. 9).

The inhibition zones $(\mathrm{mm})$ formed by the chitosan-based biocomposites showed the highest values for Candida albicans (maximum with sample C 4 with $30 \pm 0.1 \mathrm{~mm}$ and min. with sample $C 1$ with $13 \pm 0.2$ ) followed by Staphyloccoccus aureus (maximum with sample $C 4$ with $27 \pm 0.4$ and min. with sample $C 1$ with $10 \pm 0.2 \mathrm{~mm}$.) and Escherichia coli (maximum with sample $C 4$ with $25 \pm 0.2$ $\mathrm{mm}$, and min. with sample $C 1$ with $8 \pm 0.4 \mathrm{~mm}$ ). Each value is the mean \pm SD of three independent measurements. Figure 10 shows the results of variation of inhibition zones for all studied biocomposites.

In literature, several mechanisms of action have been proposed for explaining the antimicrobial activity of chitosan, among which: the interaction between positively charged chitosan molecules with the negatively charged cell membrane to alter cell permeability [28, 29]. This model is most accepted and the interaction is mediated by the electrostatic forces between the protonated $\mathrm{NH}_{3}^{+}$ groups and the negatively charged residues [30]. This electrostatic interaction results in two ways: 1 . by

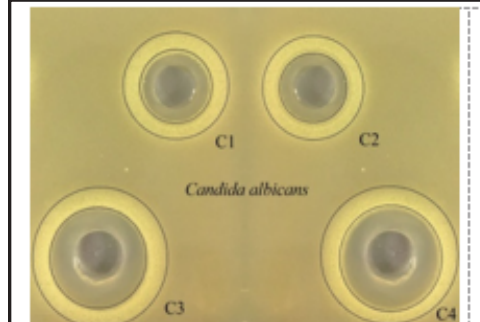

a) The antimicrobial effect exerted on C. albicans
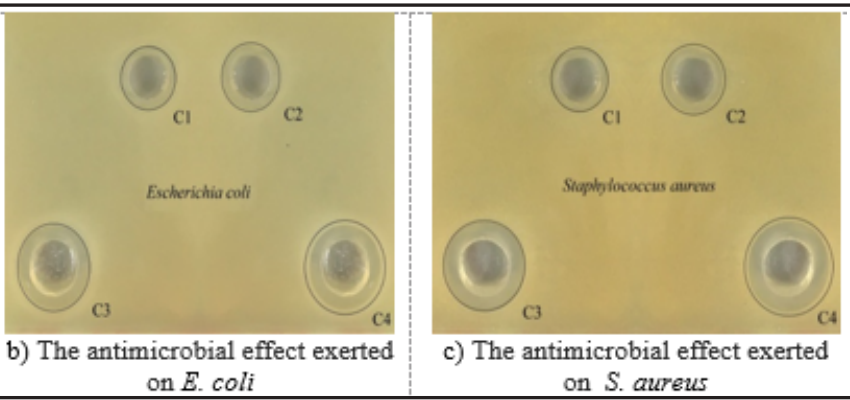

Fig. 9. Halos formed around wells filled with chitosan-based biocomposites 


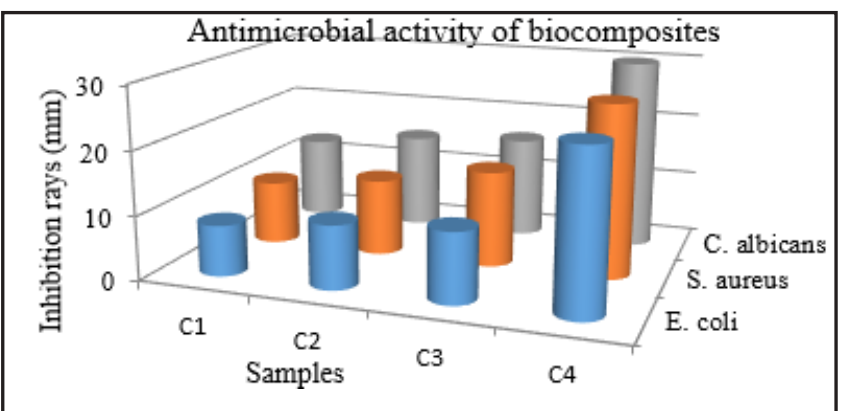

Fig. 10. Inhibition zones of chitosan based biocompostes

modifying the permeability properties of the cell membrane causing an internal osmotic imbalance and thus inhibiting the development of the microorganism [30]; and 2. by hydrolysing the peptidoglycans in the wall of the microorganism, leading to leakage of the intracellular electrolytes, magnesium ions or other low molecular weight proteinaceous constituents (nucleic acid, proteins, glucose) [31]. Another model considers binding of chitosan to microbial DNA leading to inhibition of RNA and protein synthesis by the penetration of chitosan into the nucleus of the microorganism [32]. Other mechanisms take into account the chelation of essential metals and nutrients leading to the inhibition of microbial development [33] and the formation of a polymeric membrane on the surface of the cell that does not allow nutrients to enter the bacterial cell [34] or act as an oxygen barrier that can inhibit the development of aerobic bacteria [35]. There are a number of intrinsic and extrinsic factors on which this antimicrobial effect depends, namely: degree of deacetylation, molecular weight, concentration, species of microorganisms, chitosan source and ambient $\mathrm{pH}$.

\section{Conclusions}

The chitosan-based biocomposites obtained from the Pachygrapsus Mormoratus stone crabs in the Black Sea were made in the framework of a specific research for the exploitation of the resources offered by the Black Sea at the Romanian seaside.

The extraction of chitosan from Pachygrapsus Mormoratus of the Black Sea was made for the first time and the applied technological process resulted in chitosan with the degree of deacetylation of $\mathrm{DD} \%=71.5 \%$. It is known that the applications of chitosan are conditioned by the degree of deacetylation and the molecular weight of the polymer. The applied technological process allowed us to obtain a molecular weight (Mw) of chitosan of $8,98 x$ $10^{5} \mathrm{~g} / \mathrm{mol}$.

Biocomposites made according to table 1 of the paper, following rheological tests, have the following characteristics:

- differences in appearance and color were observed, so that biocomposite samples containing hyaluronic acid (C 2 and C 4) have a finer appearance and a lighter gray color than lanolin and chitosan (C1) samples that are more granular and have a darker yellowish-gray color;

- for all analyzed samples it has been observed that it has hysteresis with different areas due to different composites;

- all analyzed samples showed a decrease in apparent viscosity with increased shear rates. The obtained results highlight a non-Newtonian, pseudoplastic and thixotropic character of the studied samples.

Antimicrobial activity tested on biocomposites reveals the best inhibition of Candida albicans, followed by Staphylococcus aureus and Escherichia coli. The sample with the highest antimicrobial activity is C 4 (code L / CT / HA / S) followed by sample C 3 (code L / CT / S), sample C 2 (code L / CT / HA) and sample C 1 (code L/CT).

These results lead to pharmaceutical forms with high stability and good consistency for use in topical applications, such as restoration of degraded skin tissues through chemical or physical lesions or in post-operative treatments.

\section{References}

1.HUANG S., FU X, J ournal of Controlled Release, 142 (2), 2010, p.149-15.

2.KIM H.N., HONG Y., KIM M.S., KIM S.M., SUH K.Y., Biomaterials 33, 2012, p. 8782-8792.

3YATES C.C., WHALEY D., BABU R., ZHANG J., KRISHNA P., BECKMAN E., PASCULLE A.W., WELLS A., Biomaterials, 28, 2007, p. 3977-3986. 4.BECHIR, A., SIRBU, R., PACURAR, M., PODARIU, A.C., MONEA, M., BECHIR, E.S., GHERGIC, D.L., Rev. Chim.(Bucharest), 65, no. 3, 2014, p. 362-368.

5.SHULMAN JD, BEACH MM, RIVERA-HIDALGO F, J, Am, Dent, Assoc. 135, 2004, p.1279-1286.

6.GONSALVES W.C., CHI A.C., NEVILLE B.W., Am. Fam. Physician, 75, 2007, p. 509-512.

7.SCULLY C., PORTER S.R., Oral Medicine for the Dental Health Team, Churchill Livingstone, Edinburgh, 2003, p. 35-69.

8.NELSON G., ALTMAN A.D., NICK A., MEYER L.A., RAMIREZ P.T., ACHTARI C., ANTROBUS J,HUANG J , SCOTT M, WIJK L, ACHESON N, LJUNGQVIST O, DOWDY S.C., Gynecol. Oncol., 140(2), 2016, p. 323-332.

9.ISHIHARA M., NAKANISHI K., ONO K., SATO M., KIKUCHI M., SAITO Y., YURA H., MATSUI T., HATTORI H., UENOYAMA M., KURITA A., Biomaterials 23, 2002, p. 833-840.

10.WINTER G.D., Nature, 193, 1962, p. 293-294.

11.MOGOSANU G.D., GRUMEZESCU A.M., Int. J. Pharm. 463, 2014, p. 127-136.

12.GONG C., WU Q., WANG Y, ZHANG D., LUO F., ZHAO X., WEI Y., QIAN Z., Biomaterials, 34, 2013, p. 6377-6387.

13.CHERIM M., STANCIU G., RASIT E. Y., CADAR E, J ournal of Science and Arts, 4(41), 2017, p. 795-802.

14.DAS T, DEBNATH J, NATH B, DASH S, Int. J. Pharm. Pharm. Sci. 6, 2014, p. 693-697.

15.SENNI K., PEREIRA 」., GUENICHE F., DELBARRE-LADRAT C., SINQUIN C., RATISKOL J., GODEAU G., FISCHER A.M., HELLEY D., COLLIEC-J OUAULT S., Mar. Drugs 9, 2011, p. 1664-1681.

16.CHERIM M., RASIT E. Y., J ournal of Science and Arts, 4(45), 2018, p. 1015-1024.

17.ALEF MUSTAFA, ANA-MARIA IONESCU, MELAT CHERIM, RODICA SÎRBU, European J ournal of Interdisciplinary Studies (EJIS), 4(2), 2016, p.271-278,

18.GHIORGHITA C.-A., BUCATARIU F., MIHAI M., DRAGAN E. S., Mat. Plast., 52, no. 1, 2015, p.51-54.

19.COJ OCARU, I., PRODAN, D., POPESCU, V., MOLDOVAN, M., Mat. Plast., 54, no. 1, 2017, p.60-62.

20.ZHENG SHU X., LIU Y., PALUMBO F.S., LUO Y., PRESTWICH G.D., Biomaterials 25, 2004, p. 1339-1348.

21.CZECHOWSKA-BISKUP R., JAROSINSKA D., ROKITA B., ULANSKI P., ROSIAK J. M, Physics Research B., 7, 2012, p. 5-20.

22.WANG, W., BO, S.Q., LI, S.Q, QIN, W., International J ournal of Biological Macromolecules. 13, 1991, p. 281-285.

23.BAUER, A.W., KIRBY, W.M., SHERRIS, J.C., TURCK, M., Am. J. Clin. Pathol. 45(4), 1966, p. 493-496.

24.KURITA K., Mar. Biotechnol. 8, 2006, p. 203-226.

25.ANDRES Y., GIRAUD L., GERENTE C., LE CLOIREC P., Environ. Technol. 28, 2007, p. 1357-1363.

26.COMA V., MARTIAL-GROS A., GARREAU S., COPINET A., SALIN, F., DESCHAMPS A., J. Food Sci., 67, 2002, p.1162 1169.

27. RAAFAT D., VON BARGEN K., HAAS A., \& SAHL H. G., Appl. Environ. Microbiol., 74, 2008, p.3764-3773. 
28.SEVERINO R., FERRARI G., VU K.D., DONSİ F., SALMIERI S., LACROIX M., Food Control, 50, 2015, p. 215-222.

29.LI Z., YANG F., YANG R., Int. J. Biol. Macromol., 75, 2015, p. 378387.

30.XING K., CHEN X.G., LIU C.S., CHA D.S., PARK H.J., Int.J. Food Microbiol., 132, 2009, p. 127-133.

31.CHIN S., CHIANGHSU Y., TZULIAO H., XUANCAI Y, Carbohydrate Polymers, 134, 2015, p. 438-44.
32.DEVLIEGHERE F., VERMEULEN A., DEBEVERE J., Food Microbiol., 21, 2004, p. 703-714.

33.LI X.-F., FENG X.-Q., YANG S., FU G.-Q., Carbohydr. Polym., 79, 2010, p. 493-499.

34. LIU H., DU Y., YANG J ., ZHU H., Carbohydr. Polym., 55, 2004, p. 291297.

35YUAN G., LV H., TANG W., ZHANG X., SUN H., Food Control, 59, 2016, p. 818-823.

$\overline{\text { Masnuscript received: } 11.12 .2018}$ 